\title{
Acid Treatment of Crushed Brick (from Central African Republic) and its Ability (After FeOOH Coating) to Adsorb Ferrous Ions from Aqueous Solutions
}

\author{
S.C. Dehou ${ }^{1}$, M. Wartel ${ }^{2}$, P. Recourt ${ }^{2}$, B. Revel ${ }^{3}$ and A. Boughriet ${ }^{*}, 2,4$
}

${ }^{I}$ Chaire Unesco "sur la gestion de l'eau », Laboratoire Hydrosciences Lavoisier, Université de Bangui, Faculté des Sciences, B.P. 908, République Centrafricaine

${ }^{2}$ Université de Lille1 Laboratoire Géosystèmes Equipe Chimie Analytique et Marine, CNRS UMR 8217, BâtC8, 59655 Villeneuve d'Ascq cedex, France

${ }^{3}$ Service RMN (Résonance Magnétique Nucléaire), Bld Langevin, Bâtiment C4, Université des Sciences et Technologies de Lille1, 59655 Villeneuve d'Ascq cedex, France

${ }^{4}$ Université Lille Nord de France, I.U.T de Béthune Département de Chimie, Rue de l'Université, B.P.819, 62408 Béthune Cedex, France

\begin{abstract}
Brick made by craftsmen in Central African Republic was treated at $50^{\circ} \mathrm{C}$ and $90^{\circ} \mathrm{C}$ with a $6 \mathrm{M}$ solution of hydrochloride acid for different time lengths. Total chemical compositions of leached samples were determined by ICPAES and their chemical, mineralogical and morphological/textural properties were characterized by using an environmental scanning electron microscope equipped with an energy dispersive X-ray spectrometer, ${ }^{27} \mathrm{Al}$ solid-state MAS NMR spectrometry, $\mathrm{N}_{2}$ adsorption - desorption (BET) method. The acid-modified brick was found to possess a higher surface area as a result of structural and compositional collapses with significant Fe an Al losses which reached up to $85 \mathrm{wt} \%$ for Fe and $55 \mathrm{wt} \%$ for Al. Pore size distributions had allowed us to show the predominance of mesoporous structures with roughly two pore-diameter maxima at $7.6 \mathrm{~nm}$ and $14.6 \mathrm{~nm}$. Higher surface acidity was also detected on HCl-treated brick pellets, indicating the generation of Brönsted and/or Lewis acid sites on their surfaces; These acid centers were evidenced by ${ }^{1} \mathrm{H}-\mathrm{MAS}$ NMR spectrometry and also by FT-IR using pyridine as a probe molecule. The quantification of these acid sites was performed firstly by pHmetry with a $\mathrm{NaOH}$ solution under a strictly controlled $\mathrm{N}_{2}$ atmosphere, and secondly by adsorption - desorption studies of pyridine versus temperature using ThermoGravimetric (TGA)/Differential Thermal (DTA) analyses and TGA coupled to Mass spectrometry. The acid treatment of brick led to a higher surface area mesoporous material that was used in the present work as an adsorbent for removing $\mathrm{Fe}^{2+}$ ions from aqueous solutions after deposition of iron oxy-hydroxides. The efficiency of this new composite was confirmed in the laboratory by carrying out fixed-bed column experiments.
\end{abstract}

Keywords: Brick, metakaolinite, ferrous ions, acid activation, adsorption, porosity, morphology, acidic surface, water treatment.

\section{INTRODUCTION}

In developing countries, ground water in rural area is often used as drinking water. These freshwaters contain frequently undesirable and naturally occurring inorganic/ organic (microbial) contaminants, and unfortunately, poverty prevents people from acquiring modern treatment technologies. To make these waters more suitable for human consumption in these countries, considerable attention has been paid to the elaboration of new drinking water treatment technologies using mainly adsorption as an effective and economic method for the removal of pollutants from contaminated waters. These technologies are based on the investigation of diverse types of low-cost adsorbents like: clays minerals [1-3]; zeolites [4]; and metal oxides [5, 6].

*Address correspondence to this author at the Université Lille Nord de France, I.U.T de Béthune Département de Chimie, Rue de l'Université, B.P.819, 62408 Béthune Cedex, France; Fax: +33(0)3 204348 22;

E-mail: abdel.boughriet@univ-lille1.fr
There are further those prepared by different kinds of waste materials: (i) from industries like: (a) fly ash as coal (or wood)-combustion residues [7-13], (b) red mud as a byproduct of bauxite [1,14], and (c) blast furnace slag [1,13]; and (ii) from agriculture like: rice, tea and coffee residues $[13,15]$. However, all these technologies are not easily applicable in rural areas of poor countries because of construction/operation/maintenance requirements. In order to adapt to local water problems of these rural communities, many authors have developed small-scale water adsorption filtration systems with raw sand or sand coated with iron oxides/hydroxides in the aim to remove quantitatively cations, anions and even bacteria from aqueous solutions [16-24].

In Central Africa Republic ground waters, that serve as sole source of drinking water in rural communities, are known to contain up to 10 milligrams of dissolved iron per liter. This explains why these waters turn easily cloudy and reddish brown color in the presence of air oxygen, and 
thereby become undrinkable, organoleptic and inappropriate to get washed and to do the laundry. To remove soluble iron from these waters, a bulk material, brick commonly made by local craftsmen was tested in our laboratory as a low cost adsorbent contrary to most of those employed for water purification treatments with possible industrial applications. This material is found to be mainly composed of sand and clays minerals. In other respect, there is evidence in the literature that clay minerals could be chemically modified to improve their adsorption capacity when they were treated with concentrated inorganic acids [25-28]. In this context, a detailed examination of physicochemical mineralogical and morphological properties of crushed brick subjected to thermal treatment and $\mathrm{HCl}$ leaching had been undertaken in the present work. The research described here was finally designed to test the performances of acid-activated brick after its iron oxy-hydroxide coating for removing ferrous ions from aqueous waters in a fixed-bed column by comparing the uptake capacity of this new composite with those obtained for untreated brick, raw sand, and iron oxides-coated sand.

\section{EXPERIMENTAL}

Bricks were made by craftsmen and used for construction activity by local people in Bangui region (Central African Republic). Bricks makers extracted starting material directly near their homes at ground depths $\geq 0.2 \mathrm{~m}$. Briefly, extracted soils were mixed with water and the obtained mud was shaped manually; Resulting air-dried (48 h) bricks were placed in efficient stackings with air flows in order to constitute a basic oven (that was built simply on ground), heat treated with dry wood for a period of about three days at temperatures ranging from $500^{\circ} \mathrm{C}$ to $800^{\circ} \mathrm{C}$, and finally cooled progressively up to ambient temperature during two/three days. In order to increase the surface area of the brick material, this latter was broken in grains manually by using a hammer; Brick particles were afterwards sieved with mechanical sieves and the fraction of particles with sizes varying from 0.7 to $1.0 \mathrm{~mm}$ was kept for our experiments. This fraction was washed with Milli-Q water and then decanted; After settling, water was eliminated and brick grains were dried at $105^{\circ} \mathrm{C}$. The dried solid particles thus obtained were ready for a $6 \mathrm{M} \mathrm{HCl}$ leaching at a constant temperature $\left(50^{\circ} \mathrm{C}\right.$ and $\left.90^{\circ} \mathrm{C}\right)$ and at different reaction times ranging from $1 \mathrm{~h}$ up to $26 \mathrm{~h}$. Afterwards, a deposition of $\mathrm{FeOOH}$ onto brick grains was performed by the precipitation of a $0.25 \mathrm{M}$ ferric nitrate solution in the presence of a $6 \mathrm{M}$ $\mathrm{NaOH}$ solution, followed by the addition of a $1 \mathrm{M} \mathrm{NaOH}$ solution in order to adjust $\mathrm{pH}$ at 6-7; And finally, the resulting pellets were washed several times with Milli-Q water in order to eliminate the excess of FeOOH not attached to grains before using them for purification of ground waters contaminated by iron(II) ions.

The alkaline fusion AFNOR procedure [29] was used in this work for carrying out the total attack of raw brick and iron-coated brick samples and the resulting solutions were analyzed by Inductively Coupled Plasma Atomic Emission Spectroscopy (ICP-AES model: Varian Vista Pro axial view) in the aim to determine the total contents of brick elements. Briefly, $200 \mathrm{mg}$ of solids were put inside a platinum crucible, heated progressively up to $450^{\circ} \mathrm{C}$ for $1 \mathrm{~h}$, and maintained at this temperature during $3 \mathrm{~h}$. After that, the crucible was cooled at room temperature, and afterwards both $200 \mathrm{mg}$ of lithium tetraborate $\left(\mathrm{Li}_{2} \mathrm{~B}_{4} \mathrm{O}_{7}\right)$ and $800 \mathrm{mg}$ of lithium metaborate $\left(\mathrm{LiBO}_{2}\right)$ were loaded in this crucible and heated at $1000-1100^{\circ} \mathrm{C}$ in order to obtain a total dissolution of the mixture in a time frame of $10 \mathrm{mn}$. After cooling, the resulting material was mixed with $200 \mathrm{~mL}$ of a $0.5 \mathrm{M}$ nitric acid solution. The concentration of element ions in the resulting solution was determined by ICP-AES.

The physical characteristics (specific surface area, specific volume and pore size distribution) of raw brick and $\mathrm{HCl}$-leached brick were determined by nitrogen adsorption isotherm analyses (BET) using Sorptomatic 1990 Carlo Erba at $77^{\circ} \mathrm{K}$.

Microphotographies of a representative brick grain before and after its acid treatment were obtained by using an environmental scanning electron microscope (ESEM, QUANTA $200 \mathrm{FEI}$ ). Its elemental analysis was performed using ESEM/EDS (ESEM, model: QUANTA-200-FEI, equipped with an Energy Dispersive X-Ray Spectrometer EDS X flash 3001 and monitored by QUANTAX-400 software elaborated by Bruker). EDS measurements were carried out at $20 \mathrm{kV}$ at low vacuum $(1.00$ Torr $)$ and the maximum pulse throughput was $20 \mathrm{kcps}$. Different surface areas ranging from 0.5 to $3.5 \mathrm{~mm} 2$ were targeted on this brick grain and examined by ESEM/EDS. Atomic quantifications were performed using Quanta 400 software, and mathematical treatments allowed us to show the reproducibility of the averaged elemental composition at the brick surface, particularly, regarding atomic $\mathrm{Si} / \mathrm{Fe}$ and $\mathrm{Si} / \mathrm{Al}$ ratios.

According to recent studies on clays [30-32], Fourier Transform Infra-Red spectroscopy (FT-IR) was used in the present work to detect Brönsted and/or Lewis acid centers on HCl-leached samples which were previously treated with pyridine. The equipment employed was a mono-reflection ATR (Attenuated Total Reflection) diamond Bruker spectrometer, model VECTOR 22 equipped with a Goldengate.

Thermo-Gravimetric Analysis (TGA) and Differential Thermal Analysis (DTA) of modified brick were performed using a TGA-DTA apparatus model: Setaram Setsys Evolution. TGA-MS analyses were also undertaken using a SETARAM apparatus model TGA-92 coupled to a Pfeiffer mass spectrometer (MS). TGA and DTA analyses were carried out at temperatures varying from RT to $400^{\circ} \mathrm{C}$; They permitted us: (a) to observe the releases of physisorbed water and pyridine adsorbed on to leached brick, and (b) to assess the proportions of water and pyridine losses from the progressively heated sample. For that purpose, about $33 \mathrm{mg}$ of brick powder were loaded in a platinum crucible and heated progressively from room temperature to $400^{\circ} \mathrm{C}$ with a heating rate of $5^{\circ} \mathrm{C} \cdot \mathrm{mn}^{-1}$ and an argon flow of $75 \mathrm{~mL} \mathrm{mn}^{-1}$.

${ }^{27}$ Al solid-state magic angle spinning NMR spectra were obtained at $208.4 \mathrm{MHz}$ on a Bruker Avance 800 (18.8T) multinuclear spectrometer equipped with a $3.2 \mathrm{~mm}$ probe. The spinning rate of the $3.2-\mathrm{mm}$ zirconia rotor was $24 \mathrm{KHz}$. Single-pulse sequences were applied with a pulse time of $1 \mu \mathrm{s}(\pi / 10$ flip angle), 1024 scans, and a recycle delay of $2 \mathrm{~s}$. The ${ }^{27} \mathrm{Al}$ chemical shifts were referenced to $\mathrm{Al}\left(\mathrm{H}_{2} \mathrm{O}\right)_{6}{ }^{3+} \cdot{ }^{1} \mathrm{H}$ solid-state magic angle spinning NMR spectra were recorded 
at $400.15 \mathrm{MHz}$ on a Bruker Avance 400 (9.4T) multinuclear spectrometer equipped with a Bruker CP-MAS $4 \mathrm{~mm}$ probe. The spinning rate of the $4-\mathrm{mm}$ zirconia rotor was $14 \mathrm{KHz}$. Depth-pulse sequences were applied with a pulse time of $5 \mu \mathrm{s}$ $(\pi / 2$ flip angle), 128 scans, and a recycle delay of $5 \mathrm{~s}$. Some ${ }^{1} \mathrm{H}$ solid-state magic angle spinning NMR spectra were further recorded at $800.13 \mathrm{MHz}$ on a Bruker Avance 800 (18.8T) multinuclear spectrometer equipped with a Bruker CP-MAS $1.3 \mathrm{~mm}$ probe. The spinning rate of the $1.3-\mathrm{mm}$ zirconia rotor was $60 \mathrm{KHz}$. Depth-pulse sequences were applied with a pulse time of $1.13 \mu \mathrm{s}$ ( $\pi / 2$ flip angle), 128 scans, and a recycle delay of $5 \mathrm{~s}$. All the ${ }^{1} \mathrm{H}$ chemical shifts were referenced to TMS.

The acid-base properties of clays and the quantification of their surface charges were previously investigated by potentiometry [33, 34]. This technique was applied in the present work to our modified brick samples in order to sustain the existence of acid sites in brick clays and to assess their contents. Briefly, inside a plastic tube leached brick pellets $(1 \mathrm{~g})$ were suspended in a $10 \mathrm{~mL}$ volume of water containing $\mathrm{NaNO}_{3}$ as an inert electrolyte at a concentration of $0.1 \mathrm{M}$ for one night. This suspension composed of well moisturized pellets was afterwards transferred into a glass reaction vessel with the further addition of $20 \mathrm{~mL}$ of the 0.1 $\mathrm{M} \mathrm{NaNO}_{3}$ solution. The resulting mixture ( $1 \mathrm{~g}$ of the material in a $30 \mathrm{~mL}$ volume) was gently stirred in order to avoid any crumbling of $0.7 \mathrm{~mm}$-diameter brick grains, and was continuously purged by ultra-pure nitrogen gas for one hour prior to titration; After that, both this stirring and $\mathrm{N}_{2}$ purge were maintained during all the titration procedure. A $5.4 \times 10^{-2}$ $\mathrm{M} \mathrm{NaOH}$ solution was added precisely by using a METROHM autotitrator (model: 736 GP TITRINO); And the $\mathrm{pH}$ was detected with an universal METROHM combination electrode which was calibrated with three commercial $\mathrm{pH}$ buffers (Merck) at $\mathrm{pH}=4,7$, and 9 before analysis. The titrant solution was added as $10-\mu \mathrm{L}$ increments and the $\mathrm{pH}$ was measured as a function of time and recorded when the $\mathrm{pH}$ drift was $1 \mathrm{mV} \min ^{-1}$. When the $\mathrm{pH}$ reached 9, the titration was stopped.

Column tests All the experiments were conducted in a glass column with an inner diameter of $1.4 \mathrm{~cm}$, a height of
$25 \mathrm{~cm}$, and a medium - porosity sintered - pyrex disc at its bottom in order to prevent any loss of material. This column was packed with an absorbent composite which contained either sand or brick as the support material. The adsorption capacity of these different absorbents was investigated for a bed height of $10 \mathrm{~cm}$. The iron(II) - containing influent $\left(\left[\mathrm{Fe}^{2+}\right]=10 \mathrm{mg} / \mathrm{L}\right)$ passed at room temperature through the column downward using a peristaltic pump at a flow rate of $10 \mathrm{~mL}$ per minute. Before being used in every experiment, about 5 bed volumes of Milli-Q water were passed through the column: (a) first in order to remove any unbound and thin particles/iron oxide(s)/hydroxide(s), (b) second to check the absence of soluble iron in the effluent by ICP-AES, and (c) third to confirm the stability of the FeOOH coating precipitated on brick grains. Effluent samples were collected at various time intervals, and the concentration of soluble iron in the effluent was analyzed with time using ICP-AES.

\section{RESULTS}

Previously [35], it was found that raw crushed brick made in Bangui region is composed of the following minerals: quartz $(\sim 61 \mathrm{wt} \%)$, metakaolinite $(\sim 21 \mathrm{wt} . \%)$, illite $(\sim 3-4$ wt. $\%)$, Fe oxides/hydroxides $(\leq 4$ wt.\%), and to a lesser extent: mica and feldspath both representing less than 2 wt.\%. The elemental analysis of our samples was performed in the present work by using the alkaline fusion AFNOR procedure [29]. Our findings allowed us to show that the acid treatment of crushed brick led to some noticeable changes into its elemental composition (see Table 1).

As a whole, the $\mathrm{HCl}$ leaching performed in the brick barely affected silicon present in this material, but rather contributed to the rapid loss of $\mathrm{Al}$ and Fe: 50 wt.\% and 85 wt. $\%$ of the total brick $\mathrm{Al}$ and Fe, respectively, after a reaction time of $3 \mathrm{~h}$ (Fig. 1). Al and Fe losses with time reached rapidly a plateau at around $2 \mathrm{~h}$, and this trend continued up to $26 \mathrm{~h}$, indicating that the structure/ composition of the resulting treated material did not change any more. This explained why we focused our attention mainly on the chemical analyses of brick pellets when leached them with a $6 \mathrm{M} \mathrm{HCl}$ solution at $90^{\circ} \mathrm{C}$ for reaction times no longer than $6 \mathrm{~h}$.

Table 1. Chemical Composition of Bangui Brick Before and After Leaching with a $6 \mathrm{M}$ HCl Solution at $50^{\circ} \mathrm{C}$ and $90^{\circ} \mathrm{C}$ and at Different Reaction Times

\begin{tabular}{|c|c|c|c|c|c|c|c|c|c|c|c|}
\hline Materials (*) & $\begin{array}{c}\text { Reaction } \\
\text { Time/h }\end{array}$ & $\underset{\%}{\mathrm{SiO}_{2}}$ & $\underset{\%}{\mathrm{Al}_{2} \mathbf{O}_{3}}$ & $\begin{array}{c}\mathrm{Fe}_{2} \mathrm{O}_{3} \\
\%\end{array}$ & $\underset{\%}{\mathrm{TiO}_{2}}$ & $\underset{\%}{\operatorname{MgO}}$ & $\begin{array}{c}\mathbf{K}_{2} \mathbf{O} \\
\%\end{array}$ & $\underset{\%}{\mathrm{MnO}}$ & $\underset{\%}{\mathrm{CaO}}$ & $\begin{array}{c}\text { Loss of } \\
\text { Ignition \% }\end{array}$ & $\begin{array}{c}\text { Total } \\
(\Sigma)\end{array}$ \\
\hline Raw Bangui brick (*) & _ & 63.43 & 19.92 & 7.03 & 2.02 & 0.42 & 1.23 & 0.03 & 0.13 & 5.97 & 100.3 \\
\hline $6 \mathrm{M}-\mathrm{HCl}$ leached brick at $50^{\circ} \mathrm{C}$ & 3 & 66.69 & 19.38 & 4.12 & 2.18 & 0.35 & 1.20 & $\leq \mathrm{DL}$ & $\leq \mathrm{DL}$ & 6.59 & 100.62 \\
\hline $6 \mathrm{M}-\mathrm{HCl}$ leached brick at $50^{\circ} \mathrm{C}$ & 6 & 67.17 & 18.76 & 2.66 & 2.25 & 0.32 & 1.17 & $\leq \mathrm{DL}$ & $\leq \mathrm{DL}$ & 6.97 & 99.41 \\
\hline $6 \mathrm{M}-\mathrm{HCl}$ leached brick at $90^{\circ} \mathrm{C}$ & 3 & 73.86 & 13.46 & 1.46 & 2.46 & 0.23 & 1.19 & $\leq \mathrm{DL}$ & $\leq \mathrm{DL}$ & 6.56 & 99.33 \\
\hline $6 \mathrm{M}-\mathrm{HCl}$ leached brick at $90^{\circ} \mathrm{C}$ & 6 & 76.28 & 11.9 & 1.25 & 2.51 & 0.21 & 1.18 & $\leq \mathrm{DL}$ & $\leq \mathrm{DL}$ & 5.87 & 99.36 \\
\hline
\end{tabular}

DL: detection limit.

(*) Raw brick from Bangui region was used in the form of pellets with diameters ranging from 0.7 to $1.0 \mathrm{~mm}$. These grains were firstly washed in Milli-Q water and dried at $60^{\circ} \mathrm{C}$ for a day; And secondly, they were leached in a $6 \mathrm{M}-\mathrm{HCl}$ solution either at $50^{\circ} \mathrm{C}$ or at $90^{\circ} \mathrm{C}$ for reaction times varying from $1 \mathrm{~h}$ to $6 \mathrm{~h}$, washed several times in Milli-Q water and finally dried at $60^{\circ} \mathrm{C}$ for 1 day. 


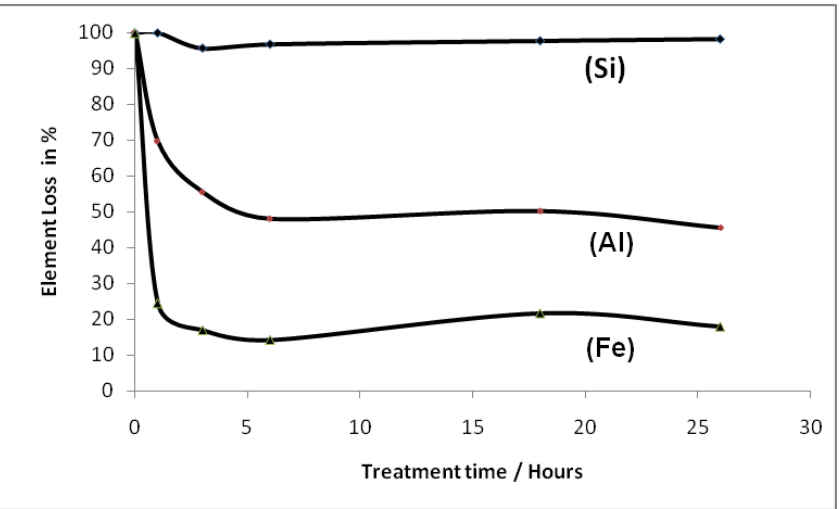

Fig. (1). Changes $v s$ leaching time of $\mathrm{Si}, \mathrm{Al}$ and $\mathrm{Fe}$ weight percentages in brick pellets treated with a $6 \mathrm{M}$ solution of $\mathrm{HCl}$ at $90^{\circ} \mathrm{C}$. $\mathrm{Si}, \mathrm{Al}$ and $\mathrm{Fe}$ contents were normalized to titanium that was found to be a stable element in the considered matrix.

As revealed in Table $\mathbf{2}$, treatment parameters particularly $\mathrm{HCl}$ concentration and reaction temperature and time had a great influence on the final meso-structure of the brick. Indeed, the surface area (S.A.) and pore volume $\left(\mathrm{V}_{\text {pore }}\right)$ of crushed brick increased notably after acid leaching from S.A. $=31.2 \mathrm{~cm}^{2} \mathrm{~g}^{-1}$ and $\mathrm{V}_{\text {pore }}=0.15 \mathrm{~cm}^{3} \mathrm{~g}^{-1}$ in the raw material to $\mathrm{S} . \mathrm{A}=76 \mathrm{~cm}^{2} \mathrm{~g}^{-1}$ and $\mathrm{V}_{\text {pore }}=0.23 \mathrm{~cm}^{3} \mathrm{~g}^{-1}$ in $6 \mathrm{M} \mathrm{HCl}$-treated solids at $90^{\circ} \mathrm{C}$ for $6 \mathrm{~h}$. In addition, the average pore diameter of brick pellets was found to decrease with a longer treatment time from $16 \mathrm{~nm}$ in the raw material to $14.1 \mathrm{~nm}$ in the leached samples after a one-hour reaction time and up to 9-10 nm after 3-6 h; Note that, as expected, when brick grains were treated at a lower temperature $\left(e . g ., 50^{\circ} \mathrm{C}\right)$, the even transformation of Bangui brick grains into more microporous structures was found to be less incomplete than that observed at a $90^{\circ} \mathrm{C}$ temperature (see Table 2): with S.A. $=46.3 \mathrm{~cm}^{2} \mathrm{~g}^{-1}$ and $\mathrm{V}_{\text {pore }}=0.157 \mathrm{~cm}^{3} \mathrm{~g}^{-1}$ at $50^{\circ} \mathrm{C}$.

Fig. (2) exhibits the mesoporous size distributions $v s$ time of brick pellets after different acid treatments carried out at two temperatures: $50^{\circ} \mathrm{C}$ and $90^{\circ} \mathrm{C}$. It can be seen broad distributions of mesopores and macropores that spread in the pore-diameter range 5-10 $\mathrm{nm}$. All the acid-treated brick samples gave narrowly mesoporous structures with pore diameters predominantly centered at $7.6 \mathrm{~nm}$ and $14.6 \mathrm{~nm}$, and their number increased progressively with increasing reaction time (see Fig. 2). Brick pellets treated at $50^{\circ} \mathrm{C}$ gave with time rather more narrowly distributed mesopores which were also centered at $7.6 \mathrm{~nm}$ and $14.6 \mathrm{~nm}$, see Fig. (2A) than those observed at $90^{\circ} \mathrm{C}$, see Fig. (2B); In other words, pore size distributions were found to be broader at $90^{\circ} \mathrm{C}$ than those observed at $50^{\circ} \mathrm{C}$.

ESEM was used to probe the change in morphological features of brick before and after the acid treatment. As a whole, the leaching procedure led to a more porous material than that before treatment, as evidenced above by BET, particularly because of two particular morphological features: rougher surfaces and the appearance of numerous cracks with sizes reaching up to $6 \mu \mathrm{m}$ in width and up to $100 \mu \mathrm{m}$ in length. Raw brick grains appeared to be highly compact compared to the texture observed for treated ones (Fig. 3). ESEM images further showed lesser cohesions between treated-brick grains, leading to a greater disaggregation of the material with more marked microcracks (Fig. 3). Using the ESEM/EDS technique, microanalyses were performed on different targeted zones of the brick with surface areas varying from 0.5 to $3.5 \mathrm{~mm}^{2}$ (by considering a brick grain targeted by the beam on a total surface area of about $5 \mathrm{~mm}^{2}$ ). Using Quanta 400 software, computational calculations permitted us to obtain an atomic quantification at the brick surface: resulting data revealed an increase of the averaged atomic ratios $\mathrm{Si} / \mathrm{Al}$ and $\mathrm{Si} / \mathrm{Fe}$ for treated brick when compared to those for untreated brick as follows: from $1.45 \pm 0.25$ to $2.42 \pm 0.45$ for $\mathrm{Si} / \mathrm{Al}$; and from $8.33 \pm 2.54$ to $37.57 \pm 8.21$ for $\mathrm{Si} / \mathrm{Fe}$. These findings corroborated with "deferrisation" and "dealumination" phenomena observed when brick pellets were in contact with a $6 \mathrm{M} \mathrm{HCl}$ solution at $90^{\circ} \mathrm{C}$, and agreed well with ${ }^{27} \mathrm{Al}$ solid NMR data and total chemical (ICP-AES) analyses described above. Microscopic-analyses data were then representative of the surface brick. However, ESEM/EDS results could differ somewhat from macroscopic ones determined by total chemical analyses, often with higher $\mathrm{Si} / \mathrm{Fe}$ and $\mathrm{Si} / \mathrm{Al}$ ratios because of greater containment of silica in the brick bulk.

According to our recent works [35], it was shown that: (i) the kaolinite clay is present in Bangui soil of Central African Republic at weight proportions varying from $20 \%$ to $28 \%$; (ii) this soil kaolinite is thermally converted into metakaolinite inside wood ovens heating at $500^{\circ}-800^{\circ} \mathrm{C}$ by

Table 2. Specific Surface Area, Pore Volume and Pore Diameter Measured on Bangui Brick Pellets Before and After their Leaching with Hydrochloride Acid at Different Reaction Times and at Two Temperatures $\left(50^{\circ} \mathrm{C}\right.$ and $\left.90^{\circ} \mathrm{C}\right)$

\begin{tabular}{|c|c|c|c|c|}
\hline Samples & Treatment Temperature & S. A. ${ }^{a}\left(m^{2} / g\right)$ & Pore Volume $\left(\mathrm{cm}^{3} / \mathrm{g}\right)$ & Average Pore Diameter (nm) \\
\hline Raw crushed brick & _- & 31.2 & 0.150 & 16.0 \\
\hline \multirow{2}{*}{$6 \mathrm{M} \mathrm{HCl}$ leached brick for 1 hour } & $50^{\circ} \mathrm{C}$ & 36.2 & 0.153 & 14.1 \\
\hline & $90^{\circ} \mathrm{C}$ & 69.1 & 0.177 & 8.6 \\
\hline $6 \mathrm{M} \mathrm{HCl}$ leached brick for 3 hours & $90^{\circ} \mathrm{C}$ & 75.5 & 0.201 & 9.1 \\
\hline \multirow{2}{*}{$6 \mathrm{M} \mathrm{HCl}$ leached brick for 6 hours } & $50^{\circ} \mathrm{C}$ & 46.3 & 0.157 & 11.0 \\
\hline & $90^{\circ} \mathrm{C}$ & 76 & 0.230 & 10.0 \\
\hline
\end{tabular}

${ }^{\mathrm{a}}$ Specific Surface area calculated by BET. 
local craftsmen; and (iii) the brick metakaolinite is a disordered (amorphous) structure generated through a dehydration of the kaolinite structure followed by its interand intra- dehydroxylation [36,37], leading to a partial transformation of six- coordinated $\mathrm{Al}$ atoms into four- and penta - coordinated Al [38-43]. Note that, as suggested previously, the diverse ${ }^{27} \mathrm{Al}$ peaks ranging from 56 to $70 \mathrm{ppm}$ (Fig. 4) may also be attributed to four-coordinated Al atoms in the illite and mica structures $[44,45]$ : indeed these two minerals are both present in the study brick at $2-4 \mathrm{wt} . \%$ and $\sim 1 \mathrm{wt} \%$, respectively.
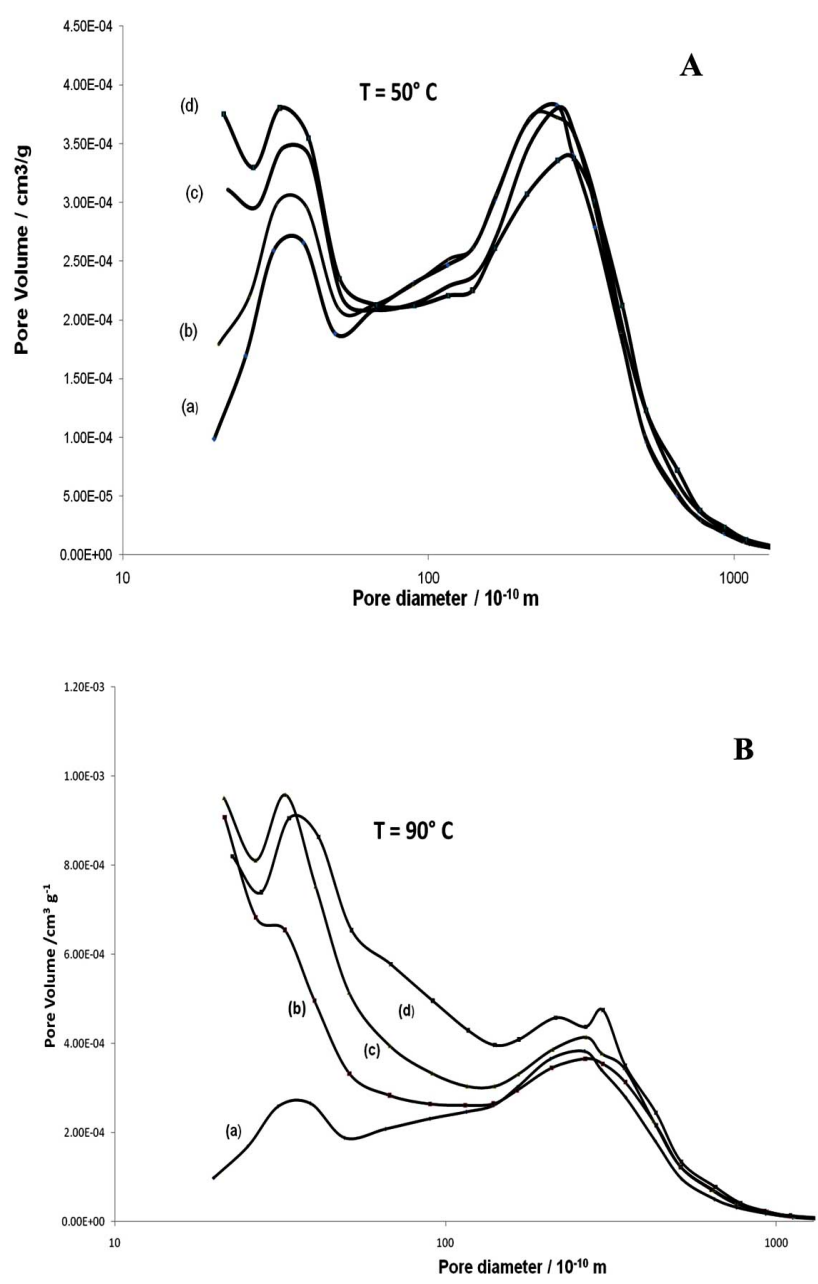

Fig. (2). Pore size distribution $v s$ treatment time of brick pellets leached with a $6 \mathrm{M}$ solution of $\mathrm{HCl}$ : at $50^{\circ} \mathrm{C}(\mathbf{A})$; at $90^{\circ} \mathrm{C}(\mathbf{B})$. Reaction times (in hours): 0 (a); 1 (b); 3 (c); 6 (d).

Furthermore, it is interesting to note that calcination temperature and firing time have strong effects on the environment of $\mathrm{Al}$ atoms, and consequently, on the observed intensities of ${ }^{27} \mathrm{Al}$ peaks assigned to the $\mathrm{Al}(\mathrm{IV}), \mathrm{Al}(\mathrm{V})$, and $\mathrm{Al}(\mathrm{VI})$ atoms of the final product: metakaolinite [42, 43]. As demonstrated above, when brick pellets were leached with hydrochloride acid, chemical analysis revealed that significant $\mathrm{Al}$ and Fe losses took place (Fig. 1), because of the easily leachable characteristics of amorphous brick metakaolinite [46]; These releases reached maximum values after about $2 \mathrm{~h}$, with losses attained up to $~ 55 \%$ for Al and $85 \%$ for $\mathrm{Fe}$ with reference to total $\mathrm{Al}$ and Fe contents in the study brick (see Fig. 1); These values were found to be in the range of those reported by Foo and his coworkers [46] for metakaolinite leached with sulfuric acid at $100^{\circ} \mathrm{C}$.

Consequently, $\mathrm{Al}$ and $\mathrm{Fe}$ losses led to significant modifications on the brick composition and therefore should contribute to relevant changes on its molecular structures and surface morphology. In order to further assess the implications of the atomic losses on the Al coordination of the study material, solid state magic angle spinning NMR analyses were performed on leached samples. In Fig. (4), it can be seen a noticeable decrease of the intensities of ${ }^{27} \mathrm{Al}$ peaks assigned to $\mathrm{Al}(\mathrm{IV})$ and $\mathrm{Al}(\mathrm{V})$ atoms which are known to be more reactive and more sensitive to acid leaching [31,47-49] and to a lesser extent, $\mathrm{Al}(\mathrm{VI})$ atoms in response to a $6 \mathrm{M}-\mathrm{HCl}$ leaching of Bangui brick; This trend was mostly observable when the material was leached at $90^{\circ} \mathrm{C}$ for $1 \mathrm{~h}$, but decreased rapidly at longer time. Therefore, these NMR investigations did reveal that Bangui brick underwent significant structural and compositional collapses accompanied with a partial dissolution of $\mathrm{Al}^{3+}$ during acid attack, in agreement with analytical data represented in Fig. (1).

On the other hand, it was previously shown that the acid leaching of metakaolinite as the predominant clay in the study brick led to a new material with less Al content, and presumably with a higher density of acid sites, as pointed out by do Nascimento and his coworkers [31]. To check this, we had undertaken the ${ }^{1} \mathrm{H}$ NMR study of $6 \mathrm{M}$ HCl-leached brick samples and shown the appearance of a broad signal between $\sim 0$ ppm and $\sim 9$ ppm centered at $\sim 5$ ppm (Fig. 5). This ${ }^{1} \mathrm{H}$ NMR resonance here differed significantly from that attributed to water molecules physisorbed and/or adsorbed on to clay surfaces (see Fig. 5). It was further noticed that after heating at $200^{\circ} \mathrm{C}$, this ${ }^{1} \mathrm{H}$ NMR resonance signal barely decreased, indicating a certain thermal stability of these ${ }^{1} \mathrm{H}$ atoms bound to the brick minerals. The generation of such acid sites in leached brick minerals resulted in fact from a relocation of Al cations from the internal structure to the newly created mesopores/clay surfaces (as pointed by Sabu and his coworkers [49]), which enabled the formation of both Brönsted and Lewis acid centers [31,46,47,49-55].

In previous works [30-32], pyridine was often used as a FT-IR probe to detect acid features in porous minerals and even to differentiate Brönsted (protonic), Lewis (aprotonic) type of clays acidity and even hydrogen-bonded sites on to their surfaces [31,52-55]. To confirm the existence of such acid sites on the surfaces of acid-treated brick, FT-IR studies were performed on our leached samples (Fig. 6). As a whole, FT-IR profiles obtained for treated brick were comparable to those found previously for acid-activated clays such as: kaolin, montmorillonite and metakaolinite [30-32]. Thus, it can be seen in Fig. (6) that the two major IR bands at 1633 $\mathrm{cm}^{-1}$ and $1540 \mathrm{~cm}^{-1}$ are assigned to vibrations of pyridinium ions generated on brick-metakaolinite surfaces through a transfer of the $\mathrm{H}^{+}$ion from the Brönsted acidic $-\mathrm{OH}_{2}{ }^{+}$center of clay mineral towards the pyridine molecule $[30,56]$. There are also weaker FT-IR bands that might be ascribed to pyridine molecules bound to Lewis acidic centers and $-\mathrm{OH}$ groups of brick clays to form hydrogen bonding (see Fig. 6), however, because of low FT-IR intensities detected, these types of bindings are undoubtedly present at lower proportions than those assigned to Brönsted ones. 


\section{Raw brick grain}

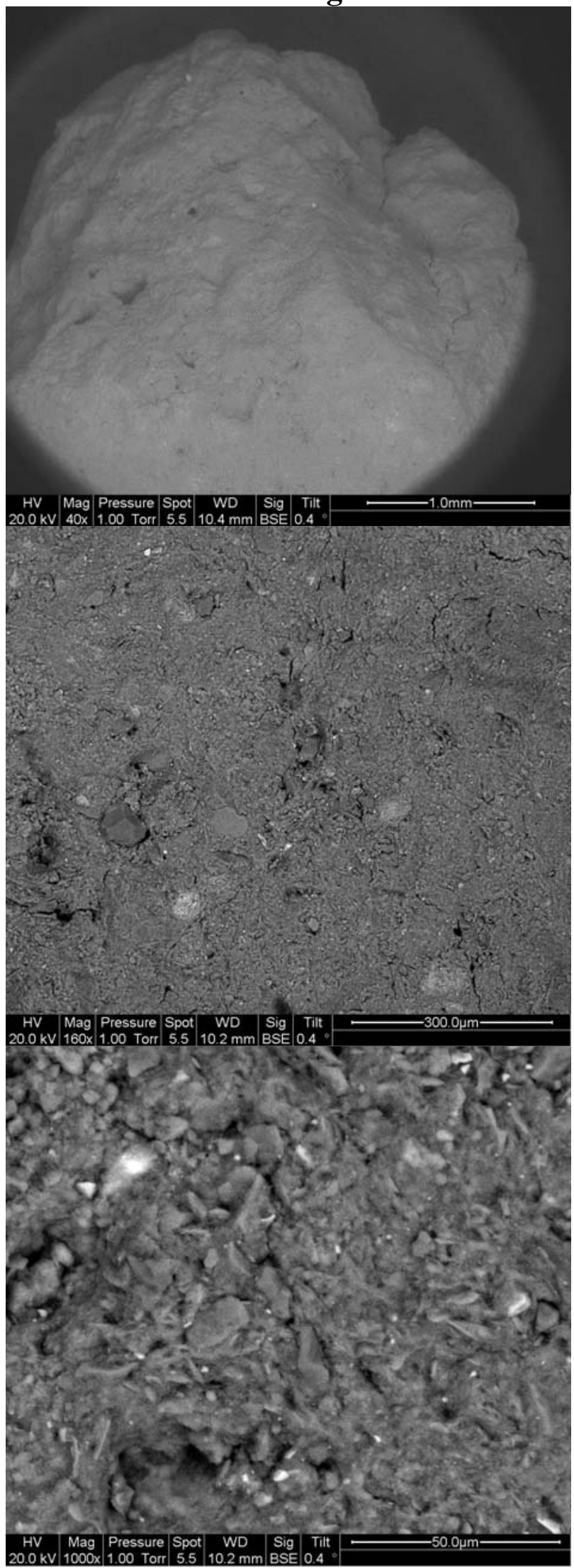

\section{M-HCl leached grain}
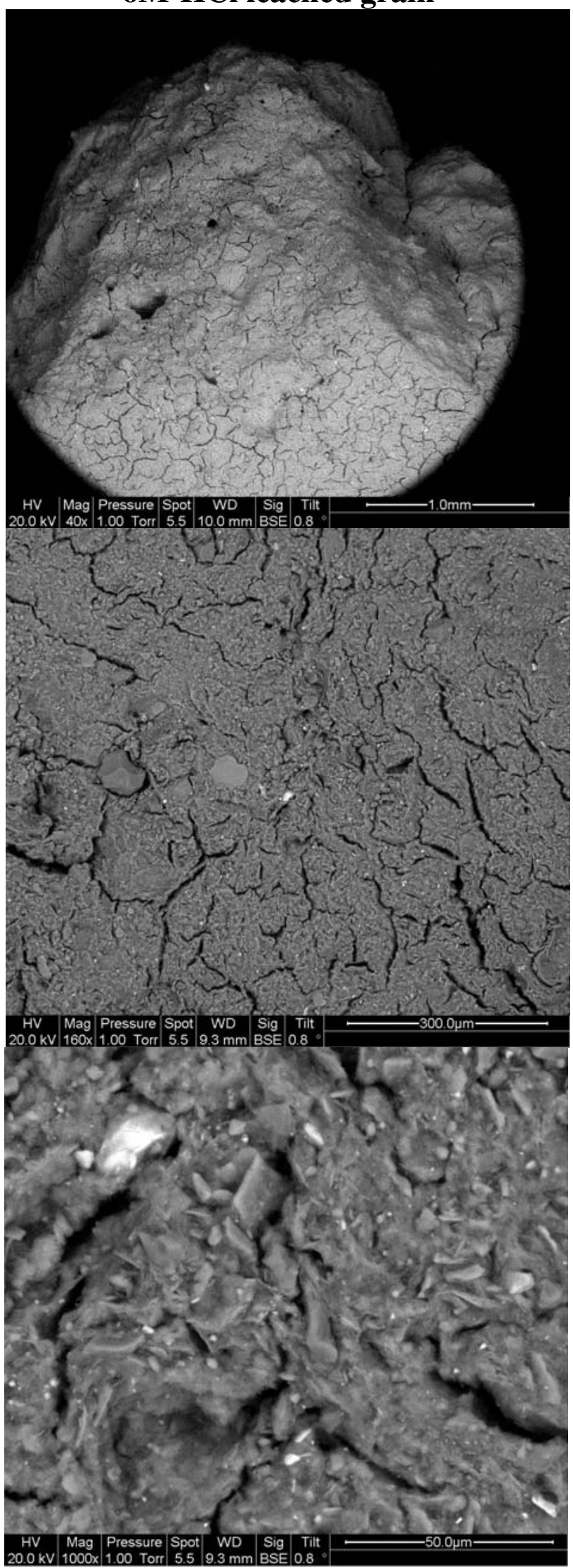

Fig. (3). ESEM micrographs obtained at three magnifications (scales used: $1 \mathrm{~mm} ; 300 \mu \mathrm{m}$; and $50 \mu \mathrm{m}$ ) for a brick grain before (the 3 photos displayed on the left) and after its leaching with a $6 \mathrm{M}$ solution of $\mathrm{HCl}$ for $3 \mathrm{~h}$ (the 3 photos displayed on the right). 

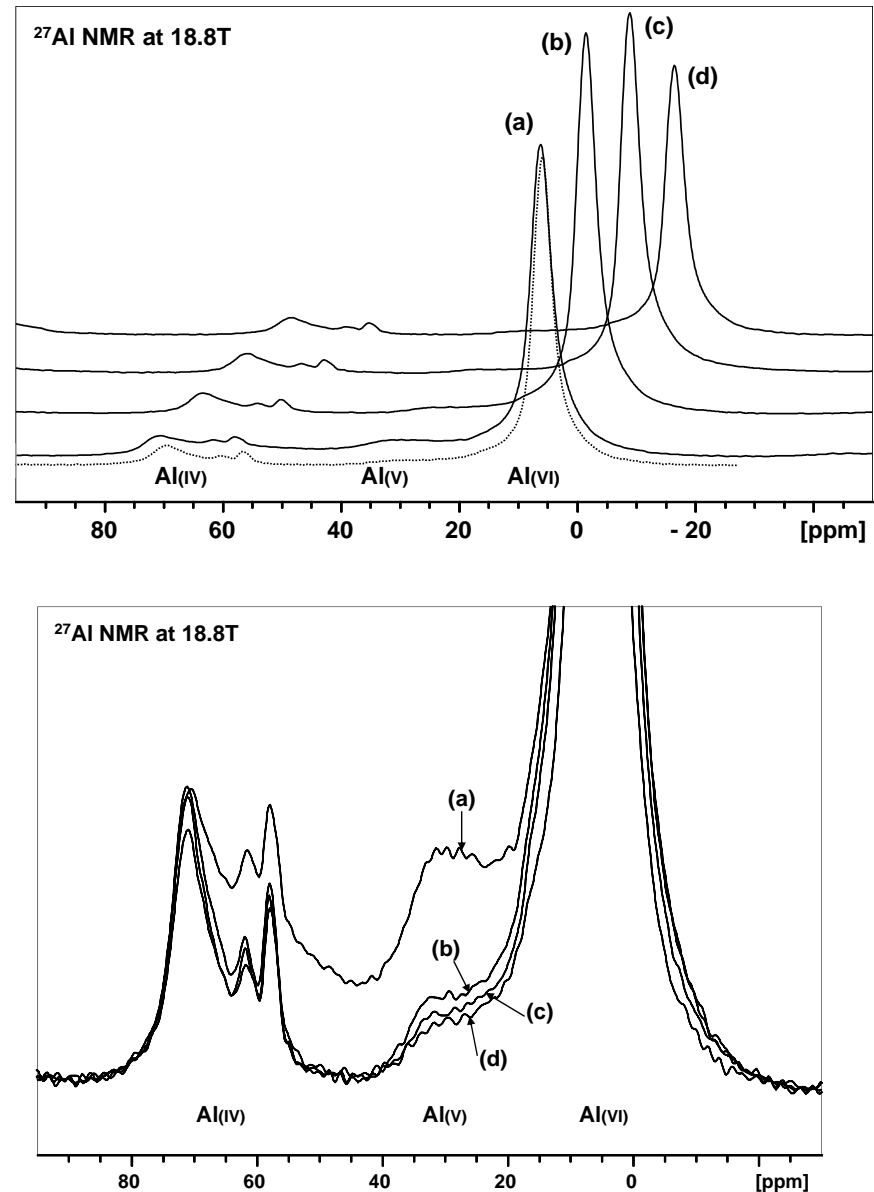

Fig. (4). Evolution $v s$ leaching time of the ${ }^{27} \mathrm{Al}$ solid state MAS NMR spectrum of $6 \mathrm{M}-\mathrm{HCl}$ treated brick.

The detailed examination of TGA-DTA curves obtained for leached brick pellets treated with pyridine (Fig. 7) also revealed that: (i) first there was initially a mass drop between RT and $200^{\circ} \mathrm{C}$ corresponding to physisorbed and interlayer water loosely bound to clays present in the study material [57-64]; and (ii) second a hardly-defined mass drop from $200^{\circ} \mathrm{C}$ up to $350^{\circ} \mathrm{C}$ which was partly attributed to the removal of strongly-bonded water molecules present in the first coordination of the interlayer ions [64] and to a continuous loss of chemically adsorbed pyridine on to brick clays as well. However, TGA-MS analysis allowed us to reveal that in the second TGA step the mass loss was predominantly due to the adsorbent pyridine (Fig. 7A). Therefore, the quantity of pyridine chemically adsorbed on the study material could be assessed (see Table 3). As a whole, we noticed that the number of acid sites in leached brick was lower than those found for activated metakaolinite [31, 49], because brick was mostly composed of sand (up to 60 wt.\%) and clays ( metakaolinite and illite, both representing less than $35 \mathrm{wt} . \%$ ). To check thermogravimetric data regarding the number of acid sites in the leached brick, we afterwards performed electrochemical studies on the material by following $\mathrm{pH}$ variation against the volume of a $5.4 \times 10^{-2} \mathrm{M} \mathrm{NaOH}$ solution under a nitrogen atmosphere strictly controlled inside all the analysis system considered (see the experimental part). Data are tabulated in Table 3.
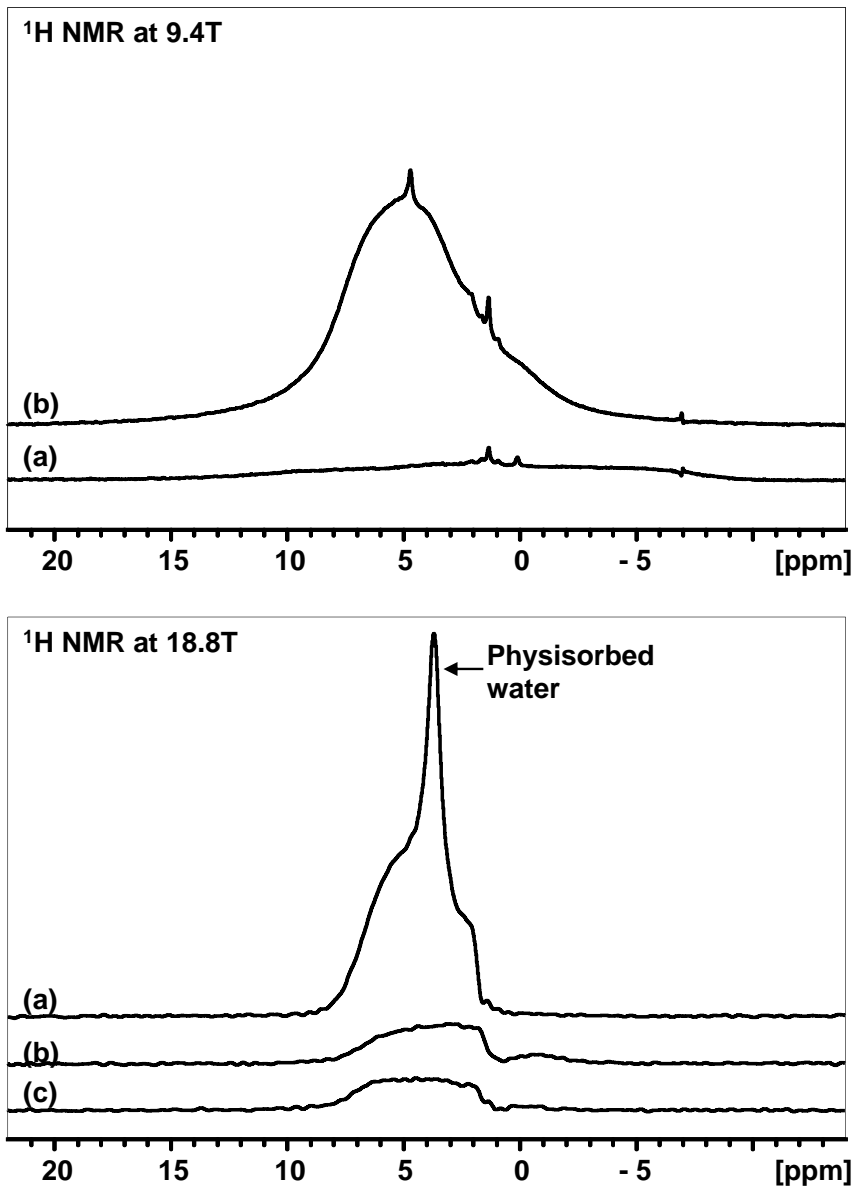

Fig. (5). Typical $1 \mathrm{H}$ solid state MAS NMR spectra of $6 \mathrm{M}-\mathrm{HCl}$ leached brick: in the presence of physisorbed water at trace levels (a); after heating at $200^{\circ} \mathrm{C}$ for $2 \mathrm{~h}$ (b); and for 1 night (c).

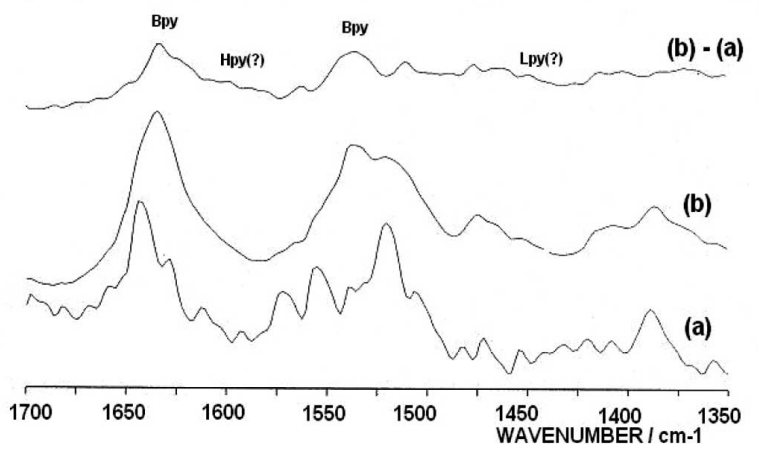

Fig. (6). Typical FT-IR spectra of $6 \mathrm{M}-\mathrm{HCl}$ leached brick: without pyridine (a); in the presence of pyridine adsorbed on to brick clays (b). Note that Bpy and Lpy represent FT-IR bands attributed to pyridine adsorbed on to Brönsted and Lewis sites of brick clays (mainly metakaolinite), respectively; And Hpy corresponds to FTIR vibrations when hydrogen bonding occurs between pyridine and nitrogen atom and $-\mathrm{OH}$ groups of brick clays (for more details, see for instance: Busca, 1999; Tyagi et al., 2006).

Overall, from our electrochemical investigations it was found that: (a) brick leached with a $6 \mathrm{M} \mathrm{HCl}$ solution for a treatment time of one hour at $90^{\circ} \mathrm{C}$ contained the highest density 
of acid sites, and (b) a longer acid treatment of brick was not favorable to the formation and stability of Brönsted and Lewis acid centers in brick clays, probably because of stronger degradations of clays surfaces (as suggested by Lenarda and his coworkers [47]). It is worth noting that proton concentrations assessed by the TGA-MS technique (see Table 3 ) were found to be lower than those measured by potentiometry, indicating that only a part of clays protons i.e., silanol and aluminol groups on clay particle surfaces was accessible to the pyridine base to generate pyridinium ions.

Column tests The properties of iron oxy-hydroxidecoated (6M-HCl pre-activated) brick, noted $\boldsymbol{I O C} \boldsymbol{B}_{(1)}$, as an adsorbent for removing ferrous ions from a synthetic solution, were examined using a fixed-bed column (for more details, consult the experimental part); And the obtained experimental data were compared to those found with other adsorbents: local raw sand $(\boldsymbol{R S})$, iron oxide-coated sand $(\boldsymbol{I O C S})$, raw brick $(\boldsymbol{R B})$, iron oxy-hydroxides-coated (1M$\mathrm{HCl}$ washed) brick $\left(\boldsymbol{I O C} \boldsymbol{C B}_{(2)}\right)$. For that, the concentration of $\mathrm{Fe}^{2+}$ ions in the effluent was plotted against filtration time, see Fig. (8).
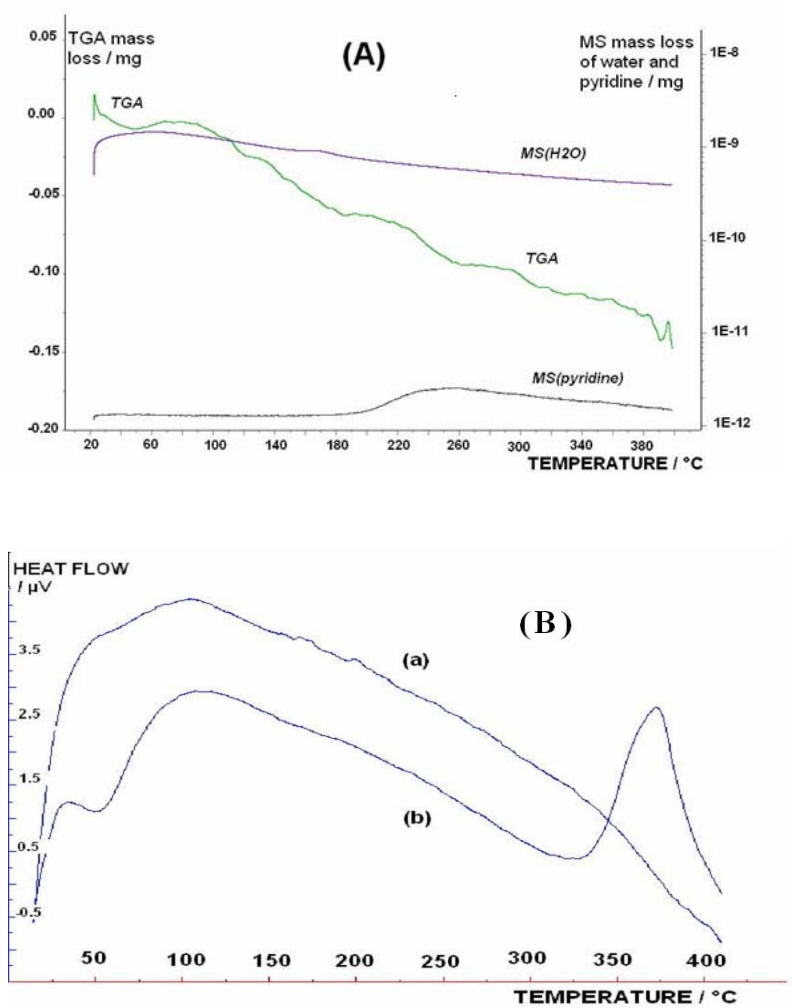

Fig. (7). (A) Thermogravimetric analysis, TGA, coupled to mass spectrometric (MS) analysis of modified brick (which was obtained after a $6 \mathrm{M}-\mathrm{HCl}$ treatment at $90^{\circ} \mathrm{C}$ for 1 hour) with adsorbed pyridine; (B) Differential thermal analysis, DTA, of this modified brick: without pyridine (a); and with pyridine adsorbed on to brick clays (predominantly metakaolinite) (b).

Breakthrough time and exhaustion time observed in Fig. (8) corresponded to two relevant filtration steps when effluent concentrations were assumed to attain about 5\% and $90 \%$ of the influent concentration, respectively. Fig. (8) indicated clearly that for $I O C B_{(1)}$ and $I O C B_{(2)}$ their breakthrough times were higher than those observed with sand adsorbents. As a whole, the improved efficiencies of $I O C B$ composites might be due to the fact that the involved adsorption was a surface phenomenon and the extent of $\mathrm{Fe}(\mathrm{II})$ adsorption was expected to be directly dependent upon the specific surface of the modified brick. In this context, it could be assumed that the formation of a higher surface area mesoporous material by acid activation (as described above) should contribute to a better deposition/spreading of iron oxy-hydroxides on to brick-clays surfaces. A mass balance for adsorbed iron showed that the $I O C B$ column used (which contained $14 \mathrm{~g}$ of material) removed $10.5 \mathrm{mg}$ of iron for $I O C B_{(2)}$ and $22.4 \mathrm{mg}$ of iron for $I O C B_{(1)}$ from the initial $\mathrm{Fe}(\mathrm{II})$ concentration of $10 \mathrm{mg} \mathrm{L}^{-1}$ during the entire filtration run: these Fe amounts corresponded to a removal capacity of $0.75 \pm 0.05 \mathrm{mg}$ Fe per gram of $\operatorname{IOCB}_{(2)}$ and $1.60 \pm 0.05 \mathrm{mg}$ Fe per gram of $\operatorname{IOCB}_{(1)}$. These values were higher than those obtained for the other tested adsorbents: (i) raw brick $(R B)$, $\approx 0.07 \mathrm{mg} / \mathrm{g}$; (ii) local raw sand $(R S), \approx 0.01 \mathrm{mg} / \mathrm{g}$; and (iii) iron oxy-hydroxide-coated sand (IOCS), $\approx 0.02 \mathrm{mg} / \mathrm{g}$.

Table 3. Determination of the Numbers of Acid Sites in the Leached Brick Pellets Using Potentiometry and Comparison of Data with those Obtained by TGAMS Method

Acid-Protons Contents (Expressed in $\mu$ mole liter $^{-1}$ ) in Brick Pellets Previously Leached at Different Reaction Times

\begin{tabular}{|l|c|c|c|c|}
\hline \hline Reaction Time: & $1 \mathrm{~h}$ & $3 \mathrm{~h}$ & $6 \mathrm{~h}$ & $22 \mathrm{~h}$ \\
\hline Techniques Used: & & & & \\
\hline Potentiometry & 28.2 & 21.7 & 16.6 & 9.6 \\
\hline TGA-MS & 7.0 & 4.3 & 3.4 & ---- \\
\hline
\end{tabular}

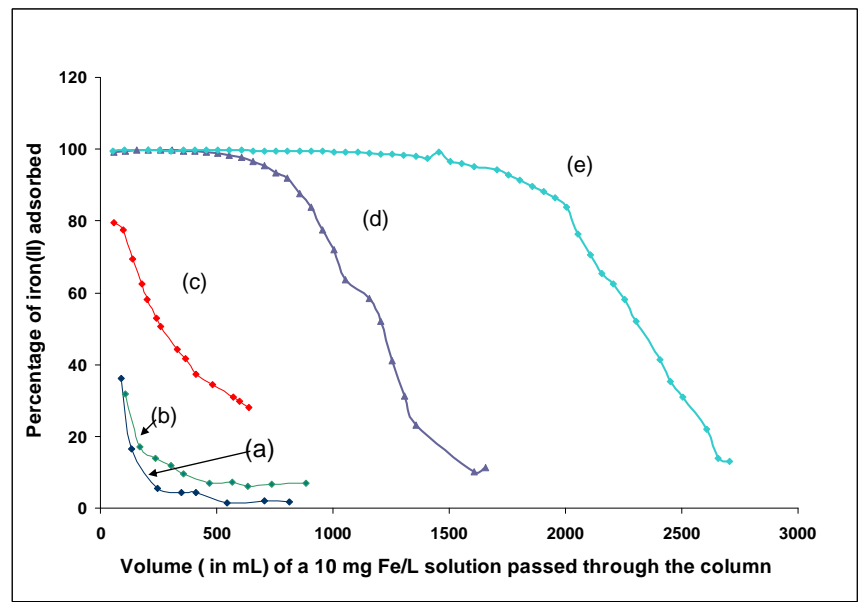

Fig. (8). Evolution of the percentage of iron(II) adsorbed on to different adsorbents as a function of the volume of a $10 \mathrm{mg} \mathrm{L}^{-1} \mathrm{Fe}^{\text {II }}$ solution passed through a glass column (which was packed with the material at a bed height of $10 \mathrm{~cm}$ ) at a flow rate of $10 \mathrm{~mL} \mathrm{mn}^{-1}$ : (a) local raw sand from Bangui region, $(R S)$; (b) Bangui sand after its FeOOH coating, (IOCS); (c) raw brick from Bangui region, $(R B)$; (d) Bangui brick treated with a $1 \mathrm{M}-\mathrm{HCl}$ solution at room temperature for 24 hours followed by its $\mathrm{FeOOH}$ coating, $\left(I O C B_{(2)}\right)$; and (e) Bangui brick treated with a $6 \mathrm{M}-\mathrm{HCl}$ solution at $90^{\circ} \mathrm{C}$ for 6 hours followed by its $\mathrm{FeOOH}$ coating, $\left(I O C B_{(I)}\right)$. 


\section{CONCLUSION}

Acid treatment of Bangui brick with hydrochloride acid at $90^{\circ} \mathrm{C}$ caused significant releases of aluminum and iron at proportions reaching up to $55 \mathrm{wt} . \%$ for $\mathrm{Al}$ and $85 \mathrm{wt} . \%$ for $\mathrm{Fe}$ (in comparison with $\mathrm{Al}$ and $\mathrm{Fe}$ contents initially present in the raw brick). The surface area of these leached samples increased notably with treatment time and their pore size distributions indicated generation mainly of mesopores with two predominant diameters: $7.6 \mathrm{~nm}$ and $14.6 \mathrm{~nm}$. On the other hand, ${ }^{27} \mathrm{Al}$ NMR was found to be a useful tool: (a) for obtaining structural information on $\mathrm{Al}$ coordination in clay minerals present in the brick, (b) for evaluating the extent of clays dealumination in response to $\mathrm{HCl}$ attack, and (c) for quantifying Al nuclei losses versus treatment time and temperature. Furthermore, both ${ }^{1} \mathrm{H}$ NMR and FT-IR (using pyridine as a probe) investigations on HCl-treated brick grains had allowed us to prove the generation of acid protons on their surfaces. FT-IR further permitted us to confirm the predominance of Brönsted protons at "brick-clays" surfaces, and their quantification was successfully accomplished by electrochemical analysis. The densities of acid sites obtained for leached samples were found to be in agreement with those reported in the literature for metakaolinite in case brick metakaolinite was considered as a mineral compound dispersed in the neutral "quartz" matrix that contained no Brönsted acidic sites. Preliminary column tests allowed us to show the good performances of this modified brick to remove iron(II) from aqueous solutions when brick pellets were coated with iron oxy-hydroxides. However, operational conditions (flow rate, bed depth and initial feed concentration) on the adsorptive behavior capacity of IOCB for $\mathrm{Fe}(\mathrm{II})$ adsorption should still be optimized, and hence, more exhaustive column experiments are under way in the laboratory. On the other hand, the better adsorptive properties of leaching brick (compared to those of raw brick) observed in the present work might be related not only to its having larger surface area, but also to the appearance of acid sites. Indeed, surface density in terms of strength and number of Brönsted acid sites should necessarily modify the zero-point charge of brick clays and thereby should facilitate the removal of cations, particularly soluble iron, from waters. To support this, more studies on ions-exchanges on brick grains surfaces are also under way in the laboratory.

\section{ACKNOWLEDGEMENTS}

This work is partly funded by: (a) "Agence de l'Eau Artois-Picardie"; (b) "Region Nord Pas-de-Calais"; (c) "Conseil Général du Nord". This study is part of the firstauthor (St C. Dehou) Ph.D. thesis, and results from the cooperation between the University of Lille1 (France) and the University of Bangui (Central African Republic). This collaboration and the Grant-in Aid to Mr. St C. Dehou for his scientific research are financially supported by the Embassy of France to Bangui. The authors are grateful to Mrs. R.N. Vannier (ENSC, Lille1, France) for TGA and DTA analyses.

\section{CONFLICT OF INTEREST}

The author(s) confirm that this article content has no conflicts of interest.

\section{REFERENCES}

[1] Malik AH. Mehmood Khan Z, Mahmood Q, Nasreen S, Bhatti ZA. Perspectives of low cost arsenic remediation of drinking water in Pakistan and other countries. J Hazard Mater 2009; 168: 1-12

[2] Mohan D, Pittman Jr. CU. Arsenic removal from water / wastewater using adsorbents - A critical review. J Hazard Mater 2007; 142: 1-53.

[3] Jiang M-Q, Jin X-Y, Lu X-Q, Chen Z-L. Adsorption of Pb(II), $\mathrm{Cd}(\mathrm{II}), \mathrm{Ni}(\mathrm{II})$ and $\mathrm{Cu}(\mathrm{II})$ onto natural kaolinite clay. Desalination 2010; 252: 33-9.

[4] Wang S, Peng Y. Natural zeolites as effective adsorbents in water and wastewater treatment. Chem Eng J 2010; 156: 11-24.

[5] Qu J. Research progress of novel adsorption processes in water purification: A review. J Environ Sci 2008; 20: 1-13.

[6] Chang F, Qu J, Liu R, Zhao X, Lei P. Practical performance and its efficiency of arsenic removal from groundwater using Fe-Mn binary oxide. J Environ Sci 2010; 22(1) :1-6.

[7] Ahmaruzzaman M. A review of the utilization of fly ash. Prog Energy Combustion Sci 2010; 36 (3): 327-63.

[8] Wang S, Terdkiatburana T, Tadé MO. Single and co- adsorption of heavy metals and humic acid on fly ash. Sep Purif Technol 2008; 58(3): 353-8.

[9] Alinnor IJ. Adsorption of heavy metal ions from aqueous solution by fly ash. Fuel 2007; 86: 853-7.

[10] Sen AK, Arnab KD. Adsorption of mercury on coal fly-ash. Water Res 1987; 21: 885-7.

[11] Panday KK, Prasad G, Singh VN. Copper(II) removal from aqueous solutions by fly ash. Water Res 1985; 19: 869-73.

[12] Rahman MH, Wasiuddin NM, Islam MR. Experimental and numerical modeling studies of arsenic removal with wood ash from aqueous streams. Can J Chem Eng 2004; 82(5): 968-77.

[13] Bhatnagar A, Sillanpää M. Utilization of agro-industrial and municipal waste materials as potential adsorbents for water treatment - A review. Chem Eng J 2010; 157: 277-96.

[14] Wang S, Ang HM, Tadé MO. Novel applications of red mud as coagulant, adsorbent and catalyst for environmentally benign processes. Chemosphere 2008; 72 (11): 1621-35.

[15] Baccar R, Bouzid J, Feki M, Montiel A. Preparation of activated carbon from Tunisian olive - waste cakes and its application for adsorption of heavy metals ions. J Hazard Mater 2009; 162:152229.

[16] Boujelben N, Bouzid J, Elouear Z, Feki M, Jamoussi F, Montiel A. Phosphorus removal from aqueous solution using iron coated natural and engineered sorbents. J Hazard Mater 2008; 151: 10310 .

[17] Arias M, Da Silva-Carballal J, Garcia-Rio L, Mejuto J, Nún̆ez A. Retention of phosphorus by iron and aluminum-oxides-coated quartz particles. J Colloid Interface Sci 2006; 295: 65-70.

[18] Han R, Zou W, Zhang Z, Shi J, Yang J. Removal of copper(II) and lead(II) from aqueous solution by manganese oxide coated sand I. Characterization and kinetic study. J Hazard Mater 2006a; B137: 384-95.

[19] Han R, Lu Z, Zou W, Daotong W, Shi J, Jiujun Y. Removal of copper(II) and lead(II) from aqueous solution by manganese oxide coated sand II. Equilibrium study and competitive adsorption. J Hazard Mater 2006b; B137: 480-8.

[20] Devi R, Alemayehu E, Singh V, Kumar A, Mengistie E. Removal of fluoride, arsenic and coliform bacteria by modified homemade filter media from drinking water. Bioresour Technol 2008; 99(7): $2269-74$.

[21] Boujelben N, Bouzid J, Elouear Z. Adsorption of nickel and copper onto natural iron oxide-coated sand from aqueous solutions : Study in single and binary systems. J Hazard Mater 2009; 163: 376-82

[22] Selvaraju N, Pushpavannam S. Adsorption characteristics on sand and brick beds. Chem Eng J 2009; 147:130-8.

[23] Yadav AK, Kaushik CP, Haritash AK, Kansal A, Rani N. Defluoridation of groundwater using brick powder as an adsorbent. J Hazard Mater 2006; B128: 289-93.

[24] Aziz HA, Adlan MN, Ariffin KS. Heavy metals (Cd, Pb, Zn, Ni, $\mathrm{Cu}$ and $\mathrm{Cr}(\mathrm{III})$ ) removal from water in Malaysia: Post treatment by high quality limestone. Bioresour Technol 2008; 99: 1578-83.

[25] Wang G, Wang X, Chai X, Liu J, Deng N. Adsorption of uranium (VI) from aqueous solution on calcined and acid - activated kaolin. Appl Clay Sci 2010; 47: 448-51. 
[26] San Cristóbal AG, Castelló R, Martin Luengo MA, Vizcayno C. Acid activation of mechanically and thermally modified kaolins. Mater Res Bull 2009; 44: 2103-11.

[27] Bhattacharyya K, Gupta SS. Removal of $\mathrm{Cu}(\mathrm{II})$ by natural and acid - activated clays: An insight of adsorption isotherm, kinetic and thermodynamics. Desalination 2011; 272: 66-75.

[28] Suraj G, Iyer CSP, Lalithambika M. Adsorption of cadmium and copper by modified kaolinites. Appl Clay Sci 1998; 13: 293-306.

[29] AFNOR (2004). Norme française NF ISO 14869-2, Nov. 2002. In : Evaluation de la qualité des sols, volume 1: Méthodes d'analyse chimique. AFNOR, Saint-Denis La Plaine (France), 2002; pp. 41118.

[30] Tyagi B, Chudasama CD, Jasra RV. Characterization of surface acidity of acid montmorillonite activated with hydrothermal, ultrasonic and microwave techniques. Appl Clay Sci 2006; $31: 16$ 28.

[31] Do Nascimento LAS, Tito LMZ, Angélina RS, da Costa CEF, Zamian JR, da Rocha GN. Esterification of oleic acid and over solid acid catalysts prepared from Amazon flint kaolin. Appl Catal B 2011; 101: 495-503.

[32] Reddy CR, Bhat YS, Nagendrappa G, Jai Prakash BS. Brönsted and Lewis acidity of modified montmorillonite clay catalysts determined by FT-IR spectroscopy. Catal Today 2009; 141:157-60.

[33] Duc M, Gaboriaud F, Thomas F. Sensitivity of the acid-base properties of clays to the methods of preparation and measurement 1. Literature review. J Colloid Interface Sci 2005; 289: 139-47.

[34] Avena MJ, De Pauli CP. Proton adsorption and electrokinetics of an Argentinean montmorillonite. J Colloid Interface Sci 1998; 202: 195-204.

[35] Dehou SC, Wartel M, Recourt P, Revel B, Mabingui J, Montiel A, Boughriet A. Physicochemical, crystalline and morphological characteristics of bricks used for ground waters purification in Bangui region (Central African Republic). Appl Clay Sci 2012; 5960: 69-75.

[36] Davidovits J, Ed. Geopolymers Chemistry and Applications. SaintQuentin, France: Institut Geopolymere 2008.

[37] Medri V, Fabbri S, Dedecek J, Sobalik Z, Tuaruzkova Z, Vaccari A. Role of the morphology and the dehydroxylation of metakaolins on geopolymerization. Appl Clay Sci 2010; 50: 538 -45.

[38] Rocha J, Klinowski J. ${ }^{29} \mathrm{Si}$ and ${ }^{27} \mathrm{Al}$ magic-angle-spinning NMR studies of the thermal transformation of kaolinite. Phys Chem Miner 1990; 17:179-86.

[39] Lippmaa E, Samoson A, Magi M. High-resolution aluminum-27 NMR of aluminosilicates. J Am Chem Soc 1986; 108: 1730-5.

[40] Klinowski J. Solid-state NMR studies of molecular sieve catalysts. Chem Rev 1991; 91: 1459-79.

[41] Fyfe CA, Feng Y, Grondey H, Kokotailo GT, Gies H. One-and two- dimensional high resolution solid-state NMR studies of zeolite lattice structures. Chem Rev 1991; 91:1525-43.

[42] Fernandez R, Martirena F, Scrivener KL. The origin of the pozzolanic activity of calcinated clay minerals: A comparison between kaolinite, illite and montmorillonite. Cement and Concrete Res 2011; 41:113 -22.

[43] Wang MR, Jia DC, He PG, Zhou Y. Influence of calcination temperature of kaolin on the structure and properties of final geopolymer. Mater Lett 2010; 64: 2551-4.

[44] Carroll DL, Kemp TF, Bastow TJ, Smith ME. Solid-state NMR characterization of the thermal transformation of a Hungarian white illite. Solid State Nucl Magn Reson 2005; 28: 31-43.

[45] Ghorbel A, Fourati M, Bouaziz J. Microstructural evolution and phase transformation of different sintered kaolins powder compacts. Mater Chem Phys 2008; 112: 876-85

[46] Foo CT, Mahmood CS, Amran Mohd Salleh M. The study of aluminum loss and consequent phase transformation in heat - treated acid - leached kaolin. Mater Characterization 2011; 62: 373-7.

[47] Lenarda M, Staravo L, Talon A, Moretti E, Riello P. Solid acid catalysts from clays: Preparation of microporous catalysts by chemical activation of metakaolin under acid conditions. J Colloid Interface Sci 2007; 311(2): 537-43.

[48] Temuujin J, Okada K, Mackenzie KJD, Jadambaa TS Characterization of porous silica prepared from mechanically amorphized kaolinite by selective leaching. Powder Technol 2001; 121: 259-62.

[49] Sabu KR, Sukumar R, Rekha R, Lalithambika M. A comparative study on $\mathrm{H}_{2} \mathrm{SO}_{4}, \mathrm{HNO}_{3}$, and $\mathrm{HClO}_{4}$ treated metakaolinite of a natural kaolinite as Friedel-Crafts alkylation catalyst. Catal Today 1999; 49:321-6.

[50] Perissinotto M, Lenarda M, Storaro L, Ganzerla R. Solid acid catalysts from clays: Acid leached metakaolin as isopropanol dehydration and 1-butene isomerization catalyst. J Mol Catal A Chem 1997; 121: 103-9.

[51] Koyuncu H, Riza Kul A, Yildiz N, Çalimbi A, Ceylan H. Equilibrium and kinetics studies for the sorption of 3methoxybenzaldehyde on activated kaolinites. J Hazard Mater 2007; 141(1):128-39.

[52] Parry EP. An infrared study of pyridine adsorbed on acidic solids Characterization of surface acidity. J Catal 1963; 2(5) : 371-9.

[53] Ghesti GF, de Macedo JL, Parente VCI, Dias JA, Dias SCL. Investigation of pyridine sorption in USY and Ce/USY zeolites by liquid phase microcalorimetry and thermogravimetry studies. Microporous Mesoporous Mater 2007; 100(1-3): 27-34.

[54] Bodoardo S, Figueras F, Garrone E. IR study of Brönsted acidity of Al-pillared montmorillonite. J Catal 1994; 147: 223-30.

[55] Carvalho AP, Martins A, Silva JM, Pires J, Vasques H, de Carvalho MB. Characterization of the acidity of $\mathrm{Al}-$ and $\mathrm{Zn}-$ pillared clays. Clays Clay Miner 2003; 51:340-9.

[56] Busca G. The surface acidity of solid oxides and its characterization by IR spectroscopic methods, an attempt at systematization. Phys Chem Chem Phys 1999; 1: 723-36.

[57] Temuujin J, Okada K, Mackenzie KJD, Jadambaa TS. The effect of water vapour atmospheres on the thermal transformation of kaolinite investigated by XDR, FTIR and solid state MAS NMR. J European Ceramic Soc 1998; 19:105-12.

[58] Kakali G, Perraki T, Tsivilis S, Radogiannis E. Thermal treatment of kaolin: the effect of mineralogy on the pozzolanic activity. Appl Clay Sci 2001; 20:73-80.

[59] Tãmăşan M, Vulpoi A, Vanea E, Simon V. Textural properties of the medical Algo clay as influenced by calcination. Appl Clay Sci 2010; 50(3) : 418-22.

[60] Ptáček P, Kubátová D, Havlica J, Brandštetr J, Šoukal F, Opravil T. The non-isothermal kinetic analysis of the thermal decomposition of kaolinite by thermogravimetric analysis. Powder Technol 2010a; 204: 222-7

[61] Ptáček P, Kubátová D, Havlica J, Brandštetr J, Šoukal F, Opravil T. Isothermal kinetic analysis of the thermal decomposition of kaolinite: The thermogravimetric study. Thermochim Acta 2010b; 501: 24-9.

[62] Cheng H, Liu Q, Yang J, Frost RL. Thermogravimetric analysis of selected coal-bearing strata kaolinite. Thermochim Acta 2010a; 507-508: 84-90

[63] Cheng H, Yang J, liu Q, He J, Frost RL. Thermogravimetric analysis- mass spectrometry (TG - MS) of selected Chinese kaolinites. Thermochim Acta 2010b; 507-508: 106-14.

[64] Panda AK, Mishra BG, Mishra DK, Singh RK. Effect of sulphuric acid treatment on the physicochemical characteristics of kaolin clay. Colloids Surf A Physiochem Eng Asp 2010; 363: 98-104. 